\title{
Development of biscuit type cookie with partial replacement of fat by inulin
}

\section{Renan Estevam Lourencetti ${ }^{1}$, Lívia Benossi ${ }^{1}$, Diego Rodrigues Marques ${ }^{1}$, Breno Miguel Joia ${ }^{2}$, Antonio Roberto Giriboni Monteiro,"}

${ }^{1}$ Department of Food Engineering, State University of Maringa, Brazil

${ }^{2}$ Department of Biotechnology Genetics and Cellular Biology, State University of Maringa, Brazil

\section{Email address:}

antoniorgm@gmail.com (A. R. G. Monteiro)

\section{To cite this article:}

Renan Estevam Lourencetti, Lívia Benossi, Diego Rodrigues Marques, Breno Miguel Joia, Antonio Roberto Giriboni Monteiro. Development of Biscuit Type Cookie with Partial Replacement of Fat by Inulin. International Journal of Nutrition and Food Sciences. Vol. 2, No. 5, 2013, pp. 261-265. doi: 10.11648/j.ijnfs.20130205.18

\begin{abstract}
Cookies are bakery products rich in fat and sugars. Lipids have in general important nutritional and technology factors, but excessive intake can bring health risks. The reduced caloric value and lipid content is a common demand among biscuits consumers, which come to own up to $60 \%$ fat. This study aimed at developing formulations of cookies with partial replacement (Standard-0\%, R1-25\%, R2-50\% and R3-75\%) of fat by inulin as well as evaluating physical, physicochemical and sensory characteristics. Through the present study, it was observed that the partial replacement of fat by inulin in the production of cookies was effective in reducing the percentage of total lipids in the final product, with maximum reduction of $86 \%$ in formulation R3, without changing the parameters for moisture, crude fiber and instrumental color. Once insulin was increased, the size of the cookies after baking decreased, therefore increasing the crispness of the cookies made from the formulation with the highest level of replacement, represented by R3, which negatively impacted the sensory evaluation of flavor and purchase intention for the product, while formulation R2, with $50 \%$ fat replacement by inulin, presented similar results to the standard product, being the formulation with the greatest sensory acceptance and physical characteristics. Therefore formulation R2 was been good in nutritional and sensorial performance, and then it is best formulation.
\end{abstract}

Keywords: Cookie, Inulin, Fat Replacement

\section{Introduction}

Biscuits type cookies are cereal based, and have high sugar and fat levels. Due to consumers demand about healthier products, such products have been increasingly required reformulation and seen as the main target of recent researches [1].

Studies have shown that there is a high correlation between the excess of fat in diets and the risk of cardiovascular diseases [2]. According to the American Heart Association [3], saturated fat is the main alimentary cause of plasmatic cholesterol levels increase. Vegetal hydrogenated fat has high levels of trans-fatty acids, which affects the factors of cardiovascular risks, once it causes an increase in cholesterolemia, elevating the LDL-cholesterol (LDL-c) and reducing the HDL-cholesterol (HDL-c), similarly to how saturated fats work [4]. This made consumers more worried about their eating habits, leading them to reduce their ingestion of lipids.[2].
Despite such problems, fat and sugar are not easily replaced, especially regarding this sort of product. Cookies in general are soft with more favored texture characteristics due to its elevated fat level [5]. Fat is present in relatively high levels, usually between 30 and $60 \%$ of the formulations, and plays an important role, lubricating the bulk, reducing beating time, raising volume, improving color, and favoring an elaboration of a soft and highly accepted product [6]. Fat also provides flavor and the taste sensation in the mouth, contributes to appearance, palatability and texture. Sucrose is one of the most important ingredients of bakery, providing volume, texture and sweetness [7].

According to Miraglio [8], the substitutes of fat are food ingredients that can replace totally or partially the lipids in the product and still provide the food with similar organoleptic properties [9]. In general, they play two roles: to reduce total lipid content and to reduce total calories [10] five terms are used to describe ingredients to be used in 
order to reduce total lipid content:

- ("fat replacer") - general term that describe any ingredient used instead of fat;

- ("fat substitute") - synthetic compound developed to replace fat without any mass change, usually chemical structures similar to fat, but more resilient against hydrolysis by digestive enzymes;

- ("fat mimetic") - compound utilized to imitate the characteristics of fat that needs high rate of water, but resist to the hydrolysis by the digestive enzymes;

- ("low-calorie fat") - synthetic triglycerides combined with non-conventional fatty acids on the glycerol chain, resulting in a reduced caloric value;

- ("fat extender") - fat system that contains a proportion of standard fats or oils combined with other ingredients.

Inulin is considered to be a fat substitute carbohydrate, or a dietetic fiber, and posses the capacity of jellification when exposed to water, it is also used as food additive, with functional probiotic properties [11]. Inulin is present as a reserve carbohydrate found in roots and tubers of plants such as the Jerusalem artichoke(helianthus tuberosus), chicory(cichorium intybus), dhalia(dhalia sp.), yacon (smallanthus sochifolius) [12]. It is formed by an heterogeneous mixture of fructose polymers. The fructose units are usually linked by $\beta 1-2$ bounds, and present one molecule of glucose at the initial section of each linear fructose chain, and this one is attached by a $\alpha 1-\beta 2$ bond, such as in the molecule of sucrose. However, its characteristic functions allow it to be appliedto different sorts of food formulations, which has increased scientific investigation on identification, extraction, and application of inulin present in different sorts of plants [13], [14]. This carbohydrate is capable of reducing water concentration during starch jellification, leading to a lower blood sugar rate. The use of inulin is promising, once it does not change nor appearance or taste, besides, it raises both softness and moisture, allowing inulin to be applied to products with high contents of starch, such as cakes and biscuits [15].

Despite the absence of evidence about toxicity or digestive diseases associated to inulin consumption, the acceptable diary ingestion (ADI) is 40 grams, according to research carried out in western USA and Europe, the average per capita daily ingestion is from 1 to 10 grams [16].

The objective of this present work was to elaborate biscuits type cookies with reduced fat percentage, through partially replacing fat by inulin, and to evaluate their physical and chemical characteristics and acceptance through sensorial analysis.

\section{Materials and Methods}

The ingredients used to produce the cookies were: wheat flour, starch, inverted sugar syrup, sugar, hydrogenated vegetal fat, salt, soy lecithin, ammonium bicarbonate, and vanilla essence, all items were acquired on local stores in the city of Maringa/PR. The inulin applied was kindly provided by Metachem Industrial e Comercial Ltda.

The base formulation to develop the cookies was proposed by Protzek [17], with some modifications. Four samples were developed, listed on table 1, with partial replacement of fat by inulin: first sample with no inulin (Standard), 25\% (R1), 50\% (R2), and 75\% of the fat by inulin (R3).

Table 1. Formulation of the cookies

\begin{tabular}{|c|c|c|c|c|}
\hline Ingredients (\%) & Standard & $\mathbf{R 1}^{1}$ & $\mathbf{R 2}^{\mathbf{2}}$ & $\mathbf{R 3}^{\mathbf{3}}$ \\
\hline Wheat Flour & 36,2 & 36,2 & 36,2 & 36,2 \\
\hline Starch & 7,2 & 7,2 & 7,2 & 7,2 \\
\hline Inverted Sugar Syrup & 7,2 & 7,2 & 7,2 & 7,2 \\
\hline Sugar & 21,7 & 21,7 & 21,7 & 21,7 \\
\hline Vegetal Hydrogenated Fat & 18,1 & 13,6 & 9,1 & 4,6 \\
\hline Sodium Chloride & 0,7 & 0,7 & 0,7 & 0,7 \\
\hline Soy Lechitin & 0,7 & 0,7 & 0,7 & 0,7 \\
\hline$\left(\mathrm{NH}_{4} \mathrm{HCO}_{3}\right)$ & 0,4 & 0,4 & 0,4 & 0,4 \\
\hline Water & 7,2 & 10,6 & 14 & 17,4 \\
\hline Vanilla Essence & 0,6 & 0,6 & 0,6 & 0,6 \\
\hline Inulin & 0,0 & 1,1 & 2,2 & 3,3 \\
\hline
\end{tabular}

${ }^{1} \mathrm{R} 1$ : Biscuit with $25 \%$ fat reduction; ${ }^{2} \mathrm{R} 2$ : Biscuit with $50 \%$ fat reduction; ${ }^{3} \mathrm{R} 3$ : Biscuit with $75 \%$ fat reduction.

Ashes, total lipids, and crude fiber of the cookies were determined according to the Analytical Standards of Institute Adolfo Lutz [18].

The cookies physical evaluation was carried out through setting their mass, diameter, and thickness before and after baking. The cookies were measured through a caliper rule, and weighted on a digital semi-analytical scale, determining next the expansion factor for the samples. (JUNG e PALHANO, 2011). All analyses were conducted in three replicates. 
In order to analyze the experimental texture a Stable Micro Systems Texture Analyzer TAXT2i (Texture Technologies Corp, England) was used as described by Oliveira [19].

The cookies coloration was determined through the CIELab System, using a digital Hunter Lab MiniScan EZ colorimeter.

The sensory analysis for the elaborated product was carried out at the laboratory of sensory analysis of the State University of Maringa. Fifty untrained tasters using a hedonic scale evaluated samples characteristics such as flavor, aroma, color and texture. The samples were codified with three digits numbers and the presentation order was randomized among the tasters (approved by the ethics committee on human research CAAE 18718013.3.0000.0104).

The results were submitted to variance analysis (ANOVA) and Tukey's test 5\% probability, using the software Statistica 7.0.

\section{Results and Discussion}

The proximate composition values are in table 2 .

Table 2. Results of physicochemical analysis on the cookies

\begin{tabular}{lllll}
\hline Analysis (\%) & Standard & $\mathbf{R 1}^{\mathbf{1}}$ & $\mathbf{R 2}^{\mathbf{2}}$ & $\mathbf{R 3}^{\mathbf{3}}$ \\
\hline Moisture & $6.8^{\mathrm{a}} \pm 0.00$ & $7.1^{\mathrm{a}} \pm 0.00$ & $7.0^{\mathrm{a}} \pm 0.01$ & $6.93^{\mathrm{a}} \pm 0.01$ \\
Ash & $1.54^{\mathrm{a}} \pm 0.25$ & $2.88^{\mathrm{a}} \pm 0.33$ & $4.10^{\mathrm{b}} \pm 0.17$ & $4.18^{\mathrm{b}} \pm 0.18$ \\
Lipids & $28.0^{\mathrm{a}} \pm 0.04$ & $14.2^{\mathrm{b}} \pm 0.04$ & $10.0^{\mathrm{c}} \pm 0.16$ & $4.0^{\mathrm{d}} \pm 0.16$ \\
\hline
\end{tabular}

*Results are expressed as mean \pm standard deviation of three replicates. Means followed by different lowercase letters in the same line are significantly different through Tukey test at the significance level was set to $5 \%$. ${ }^{1} \mathrm{R} 1: 25 \%$ fat reduced; ${ }^{2} \mathrm{R} 2: 50 \%$ fat reduced; ${ }^{3} \mathrm{R} 3: 75 \%$ fat reduced.

Among the four formulations values obtained to ash and lipids are significantly different (5\%). Formulations R2 and R3 presented higher ashes percentage when compared to standard formulation. Moisture values shown certain regularity.

Regarding the lipid content of the samples, the results showed a significant reduction between the formulations. For R1, where the proportion of fat replaced was of $25 \%$, the reduction of total lipids was of $50 \%$, when compared to standard formulation. Formulation R2 obtained even higher reduction, compared with the standard sample it was $65 \%$, and the fat replacement rate was of $50 \%$. The highest reduction was observed for formulation $\mathrm{R} 3$, the total lipids reduction was of $86 \%$. For the biscuits type cookies, the lipids reduction in the final product is directly related to the proportion of fat replaced, that means, the higher the percentage of fat replaced, the lower the total lipids in the final product.

The results obtained for moisture and crude fiber showed no significant difference, even with the addition of inulin, which is considered a dietary fiber. Its concentration in concerning the total formulation is very low, since the proportion of replacement was 4 units of fat per 1 unit of inulin [20], making it undetectable by the method of analysis proposed in this paper for any of the formulations.

The results of the physical characteristics evaluation of the cookie biscuits are shown in Table 3. As the percentage of fat replaced by inulin increases, a considerable reduction in the size of the biscuits compared to the standard formulation is noticed, reaching a reduction of $46 \%$ to $\mathrm{R} 2$ and R3 formulations after baking. A similar result was found by Zoulias et al. [7], in the formulations of biscuits and cookies with sugar replacement and 35\% fat replaced by inulin and maltodextrin, showing significantly smaller dimensions than the standard formulation. This dimension reduction can be associated with the ability of elastic recoil presented by maltodextrin and inulin. This characteristic is enhanced while baking the biscuits [7]. Fat reduction showed no significant difference in thickness, expansion and weight of the biscuits.

Table 3. Values of size, thickness, expansion factor and weight of the cookie before and after baking.

\begin{tabular}{llllll}
\hline Sample Parameters & & Standard $^{*}$ & R1 $^{* 1}$ & R2 $^{* \mathbf{1}}$ & R3 $^{{ }^{* 1}}$ \\
\hline \multirow{2}{*}{ Diameter (cm) } & Before & $5.00 \pm 0.15$ & $4.95 \pm 0.37$ & $4.95 \pm 0.42$ & $4.87 \pm 0.20$ \\
& After & $5.77 \pm 0.11$ & $5.77 \pm 0.24$ & $2.68 \pm 0.36$ & $2.70 \pm 0.21$ \\
Thickness & Before & $0.72 \pm 0.17$ & $0.70 \pm 0.40$ & $0.70 \pm 0.15$ & $0.71 \pm 0.21$ \\
$(\mathbf{c m})$ & After & $0.98 \pm 0.15$ & $0.99 \pm 0.1$ & $0.99 \pm 0.11$ & $1.03 \pm 0.05$ \\
& Before & $16.11^{\mathrm{a}} \pm 0.85$ & $15.98^{\mathrm{a}} \pm 1.10$ & $15.98^{\mathrm{a}} \pm 0.33$ & $15.97^{\mathrm{a}} \pm 0.65$ \\
Weight (g) & After & $14.62^{\mathrm{a}} \pm 0.80$ & $13.91^{\mathrm{a}} \pm 1.05$ & $13.58^{\mathrm{a}} \pm 0.11$ & $13.2^{\mathrm{a}} \pm 0.23$ \\
\hline
\end{tabular}

*Results are expressed as mean \pm standard deviation of three replicates. Means followed by different lowercase letters in the same line are significantly different by Tukey test at the significance level was set to $5 \%$. 1R1:25\% fat reduced; ${ }^{2} \mathrm{R} 2: 50 \%$ fat reduced; ${ }^{3} \mathrm{R} 3: 75 \%$ fat reduced. 
The results for color analysis are shown in Table 4. The parameters analyzed were: L (luminosity) ranging from 0 (black) to 100 (white); coordinate which varies from-a (green) $+\mathrm{a}$ (red) and also to assess the coordinate $\mathrm{b}$ variation in color between blue $(-b)$ and yellow $(+b)$. Analyzed like Jung and Palhano [21].

Table 4. Color analysis results by the CIELAB system.

\begin{tabular}{lllll}
\hline Parameter & Standard & $\mathbf{R 1}^{\mathbf{1}}$ & $\mathbf{R 2}^{\mathbf{2}}$ & $\mathbf{R 3}^{\mathbf{3}}$ \\
\hline Luminosity L & $61.03^{\mathrm{a}} \pm 2.26$ & $64.00^{\mathrm{a}} \pm 4.81$ & $63.37^{\mathrm{a}} \pm 17.02$ & $64.83^{\mathrm{a}} \pm 8.00$ \\
Coordinate a & $6.33^{\mathrm{a}} \pm 0.72$ & $4.90^{\mathrm{a}} \pm 1.99$ & $5.90^{\mathrm{a}} \pm 0.73$ & $5.27^{\mathrm{a}} \pm 8.58$ \\
Coordinate b & $30.47^{\mathrm{a}} \pm 1.37$ & $28.53^{\mathrm{a}} \pm 0.56$ & $38.20^{\mathrm{a}} \pm 3.13$ & $30.47^{\mathrm{a}} \pm 1.58$ \\
\hline
\end{tabular}

*Means followed by different lowercase letters in the same line are significantly different by Tukey test at the significance level was set to $5 \%$.

Through color analysis, it is possible to notice that the reduction of fat addition of inulin do not significantly change the cookie color, showing the capability of inulin to mimic the property of fat as a color improver. To Gaines [22] the texture is an important element in the quality of biscuit, directly affecting consumer acceptance and sales. Based on the results presented in Table 5, there is a significant direct relationship between the formulation and the texture of the cookies. The highest compression value is associated with a higher percentage of fat replaced by inulin (R3).
In their study, Forker et al. [23] describe how the incorporation of fat-replacing ingredients contribute to increase the biscuit firmness, which is directly related to the amount and type of substitute used, resembling the results found for R3. Unlike, Zoulias et al [7] found more vigorously biscuits cookies with lower percentages of replacement. Finally, in the formulation with $50 \%$ fat replaced by inulin hardness values similar to the standard sample were obtained. This result is similar to what found in this study for R2.

Table 5. Results from texture evaluation.

\begin{tabular}{lllll}
\hline Texture & Standard & $\mathbf{R 1}^{1}$ & $\mathbf{R 2}^{\mathbf{2}}$ & $\mathbf{R 3}^{\mathbf{3}}$ \\
\hline $\begin{array}{l}\text { Compression } \\
\text { Force (Kgf) }\end{array}$ & $9.27^{\mathrm{a}} \pm 6.04$ & $12.58^{\mathrm{a}} \pm 2.41$ & $9.78^{\mathrm{a}} \pm 29.26$ & $18.55^{\mathrm{b}} \pm 31.04$ \\
\hline
\end{tabular}

*Results are expressed as mean \pm standard deviation of three replicates. Means followed by different lowercase letters in the same line are significantly different by Tukey test at the significance level was set to $5 \%$. ${ }^{1} \mathrm{R} 1: 25 \%$ fat reduced; ${ }^{2} \mathrm{R} 2: 50 \%$ fat reduced; ${ }^{3} \mathrm{R} 3: 75 \%$ fat reduced.

The results of the sensorial analysis are shown in Table 6. The attributes texture and aroma did not present significantly different values. For the parameter color, formulations R2 and R3 differ significantly, contrary to the instrumental analysis pointed. This may be due to an untrained sensory panel. The flavor attribute also pointed out the difference between the sample R3 and the others, indicating that the replacement of $75 \%$ of the fat negatively impacted the taste parameter, resulting in scores lower than the others.

Table 6. Results of sensory analysis.

\begin{tabular}{lllll}
\hline Attributes & Standard $^{*}$ & $\mathbf{R 1}^{* 1}$ & R2 $^{*{ }^{* 1}}$ & R3 $^{* 1}$ \\
\hline Color & $7.50^{\mathrm{a}} \pm 1.69$ & $7.68^{\mathrm{a}} \pm 1.46$ & $7.90^{\mathrm{b}} \pm 1.25$ & $7.96^{\mathrm{b}} \pm 0.86$ \\
Texture & $6.90^{\mathrm{a}} \pm 1.97$ & $6.80^{\mathrm{a}} \pm 1.97$ & $6.81^{\mathrm{a}} \pm 2.07$ & $5.66^{\mathrm{a}} \pm 2.34$ \\
Flavor & $7.11^{\mathrm{a}} \pm 2.40$ & $7.37^{\mathrm{a}} \pm 2.20$ & $7.69^{\mathrm{a}} \pm 1.73$ & $6.88^{\mathrm{b}} \pm 2.34$ \\
Aroma & $7.38^{\mathrm{a}} \pm 2.12$ & $7.40^{\mathrm{a}} \pm 1.90$ & $7.74^{\mathrm{a}} \pm 1.13$ & $7.40^{\mathrm{a}} \pm 1.90$ \\
\hline
\end{tabular}

*Results are expressed as mean \pm standard. Means followed by different lowercase letters in the same line are significantly different by Tukey test at the significance level was set to $5 \%$. ${ }^{1} \mathrm{R} 1: 25 \%$ fat reduced; ${ }^{2} \mathrm{R} 2: 50 \%$ fat reduced; ${ }^{3} \mathrm{R} 3: 75 \%$ fat reduced.

The results for purchase intention are presented on table 7. It is observed that formulation $\mathrm{R} 2$, with $50 \%$ fat replaced, has the greatest acceptance among the samples, and sample R3 having 75\% fat replaced presented lower acceptance as shown in the table below.

Table 7. Results of purchase intention.

\begin{tabular}{lllll}
\hline & Standard & R1 & R2 & \\
\hline Certainly buy & $41.67 \%$ & $37.5 \%$ & $41.67 \%$ & $29.17 \%$ \\
Maybe buy & $35.41 \%$ & $50 \%$ & $54.17 \%$ & $37.5 \%$ \\
Would not buy & $22.92 \%$ & $12.5 \%$ & $4.16 \%$ & $33.33 \%$ \\
\hline
\end{tabular}




\section{Conclusion}

The partial replacement of fat by inulin in the production of cookies was effective in reducing the percentage of total lipids in the final product without changing the parameters of moisture, crude fiber and instrumental color. As inulin concentrations were increasing, there was a decrease in the biscuits size after baking and, consequently, an increase in the crispness on the maximum level of replacement formulation represented by R3, while formulation R2, with $50 \%$ fat replaced by inulin, presented similar results to the standard sample, being the formulation with better sensory acceptance and better physical characteristics. Therefore, the inulin ingredient can be considered as a fat mimic, efficient and feasible for formulations of biscuits type cookie, with good technological and nutraceutical properties.

\section{Acknowledgements}

The authors thank the laboratory of technology of cereals and starches of State University of Maringa. Thanks for CAPES for sponsorship.

\section{References}

[1] SILVA, M. R.; SILVA, M. A. A. P.; CHANG, Y. K. Utilização da farinha de jatobá (HymenaeastigonocarpaMart.) na elaboração de biscoitos tipo cookie e avaliação de aceitação por testes sensoriais afetivos univariados e multivariados. Ciên. Tecn. Alim., 18(1): 25-34, 1998.

[2] VIANA, R. F., SILVA, M. D. V., CARVALHO, G. M., OLIVEIRA, L. A., SILVESTRE, C. P. M.; Efeito da substituição parcial de gordura pela globina e plasma bovinos em patê de presunto. Ac. Sci. Bio. Sci., 25(1): 233-240, 2003.

[3] American Heart Association. AHA. Scientific Statement. Dietary guidelines. Revision 2000. A statement for health care professionals from the nutrition committee of the American Heart Association. Circulation 2000;

[4] RIQUE, R. B. A., SOARES, A. E., MEIRELlES, M. C.; Nutrição e exercício na prevenção e controle das doenças cardiovasculares. Rev Bras Med Esp., 8 (6): 244-254, 2002.

[5] ZOULIAS, E. I., Oreopoulou, v., Kounalaki, E.; Effect of fat and sugar replacement on cookie properties. J. Sci. Food Agric.,82 (14):1637-1644, 2002.

[6] MORAIS, K. S.; ZAVAREZE, E, R,; MIRANDA, M, A, SALA-MELLADO, M, M. Avaliação tecnológica de biscoitos tipo cookie com variações nos teores de lipídio e de açúcar. Ciênc. Tecnol. Alim., 30(1): 233-242, 2010.

[7] ZOULIAS, E. I., OREOPOULOU, V., TZIA, C; Effect of fat mimetics on physical, textural and sensory properties of cookies. Int J Food Prop 3:385-397, 2000.

[8] Miraglio, m.; Nutrient substitutes and their energy values in fat substitutes and replacers and replacers. Am. J. Clin. Nutr.,
62: $1175 \mathrm{~s}-1179 \mathrm{~s}, 1995$.

[9] LIM, J., INGLET, E. G., LEE, S.; Response to consumer demand for reduced fat foods; multifuncional fat replacers. Jap. J. Food Engin., 11 (4): 147 - 152, 2010.

[10] ROLLER, S., JONES, S.A.; Handbook of fat replacers. Weimar: Chips, 1996.p.336.

[11] O'Brein, C. M., Mueller A., Scannell, A. G. M., Arendt, E. K.; Evaluation of the effects of fat replacers on the quality of wheat bread. J. Food Engin., 56: 265-267, 2003.

[12] CHI, Z.-M., ZHANG, T., CAO, T.S., LIU, X. Y., CUI, W., ZHAO, C.H.; Biotechnological potential of inulin for bioprocesses. Biores. Techn., 102: 4295-4303, 2011.

[13] HAULY, M. C. O.; MOSCATTO, J. A.; Inulina e oligofrutose: uma revisão sobre propriedades funcionais, efeito prebiótico e importância na indústria de alimentos. Semina: Technol. Ex.,. 23(1): 105-118, 2002.

[14] ROSSI, D. M., MAGalhãES, C. R. P., KINUPP, V., FLÔRES, S. H.; Preliminary screening for the presence of inulin in food plants. Alim. Nutr., Araraquara, 22( 2): 247-250, 2011.

[15] FRANCK, A.; Technological functionality of inulin and oligofructose. Br. J. Nutr., 87(2): S287-S291, 2002.

[16] VAN LOO, J.; COUSSEMENT, P.; LEENHEER, L. De; HOEBREGS, H.; SMITS, G.; On the presence of inulin and oligofructose as natural ingredients in the western diet.Critical Reviews in Food Science and Nutrition. Boca Raton, 35 (6): 525-552, 1995.

[17] PROTZEK, E. C., FREITAS, R. J. S., WASCZYNSKJ. N.; Aproveitamento do bagaço de maçana elaboração de biscoitos ricos em fibra alimentar. B. CEPPA, 16(2): 263-275, 1998.

[18] IAL - Instituto Adolfo Lutz. Métodos Físico-Químicos para Análise de Alimentos. $4^{\mathrm{a}}$ edição. $1^{\mathrm{a}}$ Ed. Dig., 2008.

[19] OLIVEIRA, D. M. ; MARQUES, D. R. ; KWIATKOWSKI, A. ; MONTEIRO, A. R. G. ; CLEMENTE, E. . Sensory analysis and chemical characterization of cereal enriched with grape peel and seed flour - doi: 10.4025/actascitechnol.v35i3.13176. Acta Scientiarum. Technology (Online), v. 35, p. 427-431, 2013.

[20] PINHEIRO, M. V. S., PENNA, A. L. B.; Substitutos de gordura: tipos e aplicações em produtos lácteos. Alim. Nutr. $15: 175-86,2004$

[21] JUNG, D. L.; PALHANO, M. H.; Desenvolvimento tecnológico de biscoitos tipo cookies à base de farinha de berinjela. Trabalho de Conclusão do Curso (Graduação em Engenharia de Alimentos). Universidade Estadual de Ponta Grossa, 2011.

[22] GAINES C. S.; Collaborative studies on the baking quality of cookie flour by wire-cut type formulations (AACC methods 10-53 and 10-54). Cer. Foods World, 38(1): 26-30, 1993.

[23] FORKER, A., ZAHN, S., ROHM, H.; A combination of fat replacers enables the production os fat-reduced shortdough biscuits with high-sensory quality.Food Biop. Techn., 5:2497-2505, 2012. 